\title{
COP 21: \\ Kan Paris levere varen?
}

\section{Af Connie Hedegaard}

Med klimakonferencerne gælder det, at djævelen ligger i detaljen. Lederne siger pæne ting - det gjorde de også før COP15 i København. Alle siger, at nu skal det være. Men når det er FN, vi taler om, så skal der ikke mange lande til at ødelægge den gode stemning, for i princippet skal alle være enige, før der er en aftale.

I referaterne kan jeg læse, at Claudia is back:

“... Og jeg er endda rejst helt fra Bruxelles, og så skal jeg stå model til dette!”

Nogenlunde sådan indledte Claudia Salerno fra Venezuela sin bandbulle mod retningen i klimaforhandlingerne under oktobers sidste runde formelle forhandlinger før decembers klimakonference i Paris, COP 21.

At den tidligere venezuelanske chefforhandler, der nu er blevet sit lands ambassadør til EU, havde rejst $232 \mathrm{~km}$ gjorde næppe stort indtryk på kollegerne i de andre delegationer, der for størsteparten har rejst mange gange $232 \mathrm{~km}$ for at kunne forhandle i Bonn, hjemstedet for FN's Klimasekretariat UNFCCC. Eksempelvis tager det sædvanligvis forhandlerne fra de fjernt- og lavtliggende stillehavsøer en 3-4 dage at nå frem.

Citaterne fra en ophidset Claudia bragte mindelser om de sidste timer under COP15 i København. Det var hende, der hamrede sit skilt så aggressivt ned i Bella Centrets borde for at tiltrække sig Lars Løkkes opmærksomhed, at hun som en anden Jesus rakte en bloddryppende hånd i vejret forurettet over, at den danske statsminister "helt udemokratisk" ikke gav hende ordet. Hvortil statsministeren noget sammenbidt replicerede, at han ikke tog imod demokrati-lektioner fra Venezuela.

Ak ja, those were the days.

Men Claudias genopstandelse på klimascenen på den sidste forhandlingssession i Bonn, før det går løs i Paris, og med stærk retorik om at bibeholde den gamle opdeling imellem i- og u-lande, er et vidnesbyrd om, at ingen må tro, at Paris er 'a walk in the park.

\section{Gode nyheder og fremskridt}

Heller ikke selv om de sidste mange måneder har budt på mange gode nyheder og fremskridt: EU fik sine ambitiøse klimamål for 2030 igennem sidste år. Fra 20 pct. $\mathrm{CO}_{2}$

Connie Hedegaard er forhenværende EU-kommissær og minister i Danmark, senest som minister for FN's klimakonference i København i 2009. I perioden 2004 til 2009 var hun miljøminister og herefter klima- og energiminister. 


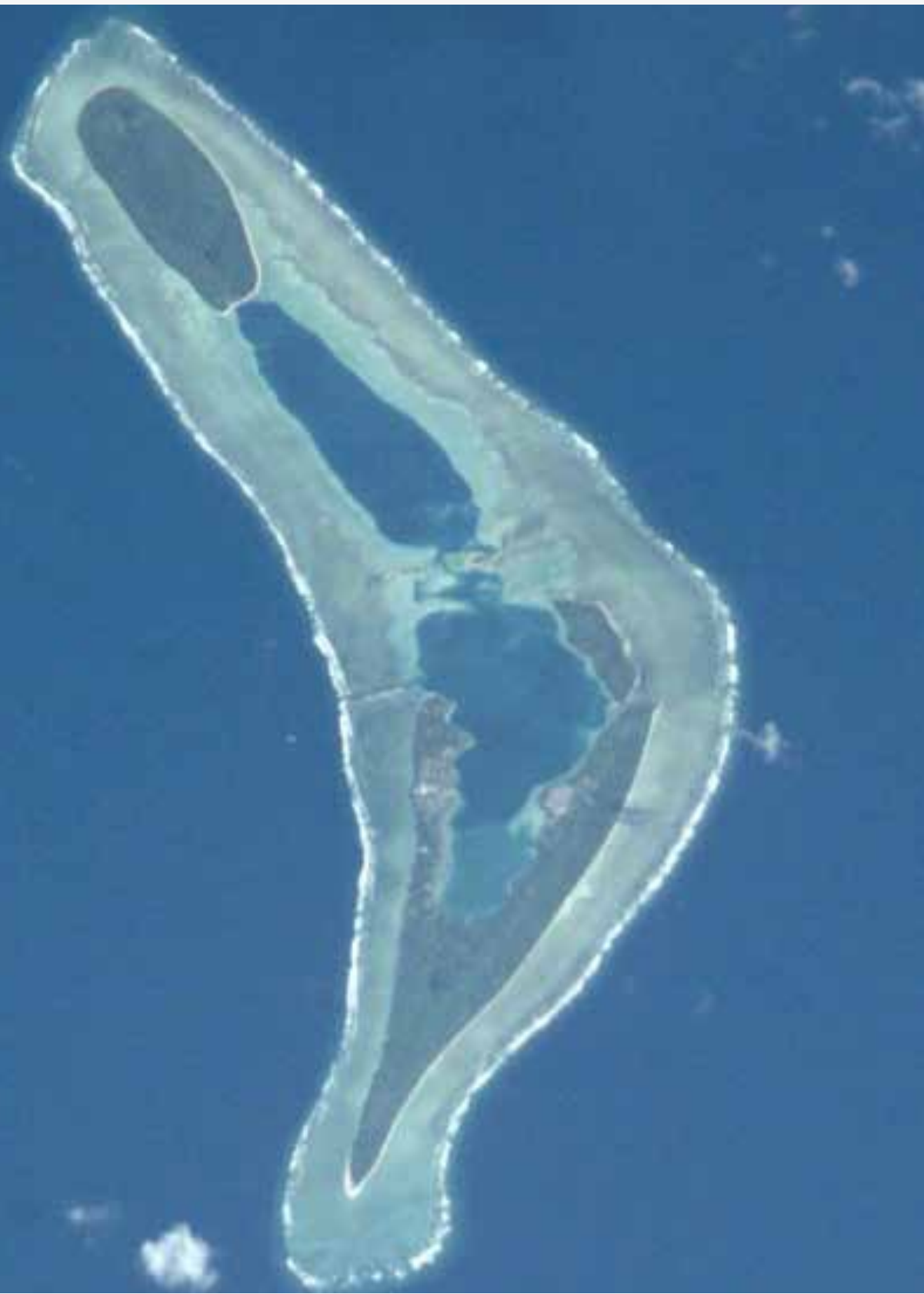

FOTO: NASA, via Wikimedia Commons.

Atollen Nanumea, Tuvalu. Verden oplever stadig flere tegn på klimaforandringer. 39 år i træk har den globale gennemsnitstemperatur ligget over gennemsnittet for det 20. århundrede. En af konsekvenserne af global opvarmning er at vandstanden i havene stiger. Dermed risikerer mange lavtliggende øriger langsomt at blive spist af havet. Det gælder fx stillehavsøriget Tuvalu, hvis højeste punkt ligger bare fire meter over havets overflade. 
reduktion i 2020 til mindst 40 pct. reduktion ti år efter, hvorved man har sat kurs mod et lavemissionssamfund i 2050.

Måneden efter fulgte for første gang et fælles tilsagn fra verdens to største udledere, USA og Kina. Da USA's Præsident Obama og Kinas Xi Jinping under et G2 møde i november 2014 annoncerede, at de begge var klar til at forpligte sig over for resten af verden, gjorde de op med det 'After You Sir, syndrom' som verdens to største udledere har holdt hinanden i skak med alt, alt for længe: USA har ikke villet rykke sig, før Kina gjorde det, og klart nok mente Kina på sin side ikke, at de skulle flytte sig, før den gamle industrination USA gjorde det. Resultatet har været kollektiv stilstand, og bl.a. under klimakonferencen i København så man resultatet af, at de to store holdt hinanden i skak på laveste fællesnævner.

Med Kinas og USA's respektive annonceringer af for USA's vedkommende et reduktionsmål og for Kinas et løfte om hvornår deres udledninger senest vil toppe, gik klimaforhandlingerne ind i en ny fase - også uanset at begge parters ambitionsniveau på ingen måde var imponerende. Samtidig er en ny regering i Australien og en ditto i Canada også godt nyt for klimaet. Den Grønne Klimafond, der blev vedtaget i København, og som skal bidrage til at støtte klimavenlige projekter og teknologier, er ikke bare kommet op at stå, den er nu også begyndt at støtte konkrete projekter. Og flere og flere ulande har indset, at 'det der med klimaet' ikke er et luksusproblem, der kan vente til fattigdommen er bekæmpet, børnene uddannet og udviklingsplanerne lagt, men tværtimod må tænkes integreret ind i samme udviklingsplaner.

Det kræver investeringer, og en anden positiv nyhed er, at verden over begynder investeringsstrømme at orientere sig mere efter vedvarende energi og grønne løsninger og mindre efter fossile brændstoffer, hvor især kul rammes af skiftet i investorernes fokus. Også byerne rykker. I dag kan man ikke være borgmester i en bare nogenlunde stor by og så ikke vide, hvad ens klimaregnskab er for noget. Det samme gælder for meget af det store erhvervsliv, hvor klima ikke længere er noget, der klares hos en miljøafdeling nede i systemet. Nej klima er rykket ind på direktionsgangen, ind til det øverste ledelseslag, hvor det også hører hjemme, præcis ligesom klima ikke kun er et anliggende for miljø- og klimaministre men også for finansministre og regeringschefer.

Jamen, hvor svært kan det så være, tænker læseren nok. Og svaret er: stadig uhyre svært.

\section{Det er FN vi taler om}

For med klimakonferencerne - COP betyder Conference of the Parties - gælder det i sjælden grad, at djævelen ligger i detaljen. Ja, lederne siger pæne ting - det gjorde de også før København.

Der kommer gode erklæringer og papirer ud af G7, G20 og alskens bi- og multilaterale møder. Det gjorde der også før København.

Alle siger, at nu, nu, nu skal det være... det gjorde de også før København.

Men når det er $\mathrm{FN}$, vi taler om, så skal der ikke mange parties, lande, til at ødelægge den gode stemning, for i princippet skal alle være enige, før der er en aftale.

Som i alle den slags sammenhænge forhandler man naturligvis på basis af en tekst, som to udvalgte forhandlere, 'Chairs' - typisk én fra Nord hhv. én fra Syd - er tovholdere for og penneførere på. Da forhandlerne i oktober mødtes i Bonn, havde de to Chairs vovet det ene øje og re- 
duceret den formelle forhandlingstekst fra 80 uhåndterlige sider til 20 . Men da de delegerede rejste hjem fra Bonn, var teksten igen svulmet op til nu 55 sider med over 1000 såkaldt kantede parenteser, dvs. alternative formuleringer, løsninger og forslag som der altså stadig ikke er enighed om, når de delegerede ankommer til slutspillet i Paris. Fra København ved vi, at man ikke skal undervurdere dynamikken omkring den formelle tekst. Uanset de politiske lederes velvillige udtalelser, skal velviljen i sidste ende omsættes til ord, der binder i en aftale.

\section{Durban 2011}

Når der overhovedet er sat en deadline for forhandlingerne, der hedder Paris 2015, går det tilbage til klimakonferencen i Durban i Sydafrika i 2011.

To år forinden var man i København trods alt - blevet enige om at omsætte videnskabens advarsler til et fælles løfte om, at verden skal holde sig under en to grader gennemsnitlig temperaturstigning. Et meget stort antal lande begyndte op til og i kølvandet på COP15 at lovgive om klima og sætte sig klimamål - noget EU indtil da havde været ret alene om. Man var også blevet enige om at etablere den grønne klimafond og om en finansieringsramme, hvor ilandene forpligtede sig til at sikre 100 milliarder dollar årligt i privat og offentlig finansiering. Og der var blevet leveret på regler for bl.a. skov.

I 2011 i Durban var der kun et år til den gamle Kyoto-aftale fra 1997 udløb. Derfor hastede det med at finde ud af, hvad der derefter skulle ske. For EU var det et hovedkrav, at en kommende ny aftale måtte gælde for alle lande. Ikke sådan at alle skal gøre lige meget på samme tid. De industrialiserede lande, som indiskutabelt har bidraget mest til klimaproblemet historisk, må reducere mere og tidligere end udviklingslandene. Men klimaligningen kan ikke løses, hvis ikke alle lande og især alle store udledere bidrager og forfølger en mere bæredygtig og klimavenlig vækststrategi.

Traditionelt har Kina i FN-sammenhæng gennem sit tilhørsforhold til 'G77 + Kina' (i alt 133 lande) slået på sin status som uland, og Kina har igen og igen forsvaret den binære opdeling fra Kyoto-aftalen om, at ilandene skal reducere, mens ulandene inklusive altså Kina blot skal gøre det, hvis de vil.

Indiens position er den samme dog med den stramning, at de længe har insisteret på at tage afsæt $\mathrm{i}$ landenes akkumulerede historiske udledninger. Det lyder måske umiddelbart retfærdigt men er reelt umuligt, da det ville betyde at de industrialiserede lande ville skulle stoppe deres udledninger helt og øjeblikkeligt, hvilket alle ved aldrig kommer til at ske.

Så i Durban ville vi fra europæisk side have trukket diskussionen ind i det 21. århundredes virkelighed, som ikke er den gamle Nord-Syd inddeling men derimod en virkelighed, hvor vi er gensidig afhængige af og forbundne med hinanden gensidigt interdependente. Derfor må alle have et medansvar for at løfte globale udfordringer, og selv om nogle må løfte mere end andre, må alle affinde sig med at blive kigget i kortene. I den verden vi lever i, er jeg afhængig af om du gør det du siger, du gør, ligesom det kan have konsekvenser for dig, om jeg gør hvad jeg siger, jeg gør.

I princippet er EU, USA og andre ilande enige på dette punkt, men dels havde USA tilsyneladende ikke noget stærkt ønske om at gå videre end den løse ikke-bindende Københavns-aftale, dels var de ikke mindst på grund af den vanskelige situation i Kongressen derhjemme alt andet end vilde med at sætte en ny deadline. Og da 
slet ikke én der lå inden udløbet af Obamas anden og sidste valgperiode. Så paradoksalt nok havde Indien, Kina og USA en fælles interesse $i$, at Durban ikke leverede alt for meget.

Når det alligevel lykkedes, skyldtes det at EU og repræsentanter for næsten 100 udviklingslande fandt sammen i at lægge et fælles pres på de store, der så i absolut sidste sekund måtte acceptere, at fremtidens aftale skal være bindende (hvor bindende er et af de kontroversielle spørgsmål i Paris), at alle rig som fattig skal bidrage til problemets løsning omend naturligvis med forskellige bidrag, og deadline blev sat til 2015.

Da flere af de små udviklingslande med meget små administrationer og miljøforvaltninger sagde, at de da nok mente at kunne nå at formulere deres fremadrettede strategier på fire år, virkede det lidt kunstigt, at f.eks. USA og Kina i lang tid stod fast på, at der var behov for mere tid. Samtidig har det jo længe stået klart, at tid ikke just er det, der er mest af, hvis man vil håndtere klimaforandringerne på en gradvis og nogenlunde samfundsøkonomisk håndterlig måde. Jo længere man udskyder handling, desto mere alvorligt bliver konsekvenserne både menneskeligt og økonomisk set.

\section{Presset på Paris}

Deraf presset på Paris for nu at levere en overordnet ramme. Samtidig er den videnskabelige case bare blevet stærkere og stærkere år for år. Og verden oplever stadig flere tegn på, at klimaforandringerne ikke alene er en bekymring for fremtiden. De er her allerede. 39 år i træk har den globale gennemsnitstemperatur ligget over gennemsnittet for det 20. århundrede. Ni af de ti varmeste år, der nogensinde er registreret, ligger i dette unge århundrede. 2014 er det varmeste år, der er registreret - en rekord meteorologerne forventer bliver slået af 2015 .

Men ét er tal og statistikker, noget andet er, hvordan det forandrede klima og den globale opvarmning viser sig.

Faktum er, at mere og mere voldsomt og uforudsigeligt vejr, som vi ser det snart her snart der, passer uhyggelig godt med, hvad forskerne har advaret os imod, alt imens $\mathrm{CO}_{2}$ indholdet i luften stiger, og det samme gør temperaturerne. Ifølge World Meteorological Organization, WMO, vil den globale gennemsnitstemperatur for 2015 for første gang i al den tid, man har kunnet måle temperaturen, være steget med over 1 grad.

\section{Klimaet som trusselmultiplikator}

I sagens natur er det uhyre kompliceret at koble den enkelte særlige og usædvanlige vejrsituation til 'klimaforandringer'. Klimaforandringer er noget, der registreres over lange tidserier. Men alligevel er tendensen så klar, at man fx. i det sikkerhedspolitiske establishment inklusive i Pentagon taler om klima som 'a threat multiplier' - altså noget, der bidrager til at gøre andre trusler værre.

Et meget aktuelt eksempel er Syrien. Forskere fra University College London og Columbia påviste i et studie fra foråret 2015 en sammenhæng mellem klima og borgerkrigen i Syrien: I 2007 begyndte en uhyre voldsom og langvarig tørke i Syrien. Tørken fortsatte i 2008, $2009 \mathrm{og}$ ind i 2010 og var så alvorlig, at 1,5 millioner mennesker drog fra landområderne ind til de syriske byer, der allerede havde rigeligt at gøre med at absorbere flygtninge fra Irak-krigene. Dertil kom naturligvis Assad's autoritære regime.

Så det var flere ting, der til sammen udløste borgerkrigen, men ifølge forsker- 
"I har simpelt hen ikke forstået, hvad klimaforandringerne betyder for den vækst, I så gerne vil have. I investerer alt for meget i bakspejlet, til gårsdagens samfund, i stedet for at tænke klima mere konsekvent med ind i jeres investeringer. Hvis I ikke snart forstår det, får I aldrig den vækst, I så gerne vil have". [Verdensbankens chef Jim Kim ved World Economic Forum i Davos i januar 2013]

ne er Syrien et eksempel på klima som ‘a threat multiplier'. Konsekvenserne af borgerkrigen kender vi nu - i form af millioner af flygtninge, der bl.a. har sat kurs mod Europa med de enorme udfordringer og den destabilisering det giver.

\section{Vedvarende energi}

I takt med at bevidstheden om, at klimaforandringerne skal håndteres parallelt med at stadig flere mennesker kræver stadig mere vækst, vokser, ja så vokser også efterspørgslen efter renere løsninger.

I følge Bloomberg New Energy Finance blev der i 2014 globalt installeret mere ny vedvarende energikapacitet end ny kapacitet baseret på fossile brændstoffer, kul, olie og gas. Og i og med at markederne for vedvarende energi vokser stejlt, ja så er prisen faldet drastisk. Landbaseret vindog solenergi er allerede ved at være konkurrencedygtig uden støtte, og havmøller og andre teknologier følger efter i den nedadgående priskurve.

Endelig begynder investorerne som nævnt at interessere sig mere for risikoen ved at have langsigtet kapital bundet i fossile brændstoffer. Hvis verden tager klimaudfordringen alvorlig, og regeringerne rent faktisk enes om de tiltag, der skal til, for at holde sig under de to grader, ja så skal nogle af de allerede i dag kendte reserver af kul, olie og gas blive i jorden, det vil sige, at prisen på selskaberne har udsigt til at falde.

Fremtidens pensionsopsparere - og forvalterne af fremtidens pensioner - er i stigende grad opmærksom på problemstillingen, der i dag optager så forskellige aktører som Bank of England, OECD, IMF og Verdensbanken, den norske oliefond og mange andre. Herhjemme meddelte Nordens største bank, NORDEA, i februar 2015, at de går ud af kul, som i øvrigt er den store taber på tidens aktiemarkeder. Alene i USA har kulselskaberne tabt ca. 80 pct. af deres værdi siden 2013.

Noget kunne altså tyde på, at nogle grundlæggende pointer er ved at gå op for stadigt flere, og at klima i stigende grad ikke kun er et anliggende for miljøfolk. Da Verdensbankens dengang nytiltrådte chef Jim Kim i januar 2013 skulle tale ved World Economic Forum i Davos om verdens økonomiske tilstand, gav han de tilstedeværende ledere en opsang: I har simpelt hen ikke forstået, hvad klimaforandringerne betyder for den vækst, I så gerne vil have. I investerer alt for meget $\mathrm{i}$ bakspejlet, til gårsdagens samfund, $\mathrm{i}$ stedet for at tænke klima mere konsekvent med ind i jeres investeringer. Hvis I ikke snart forstår det, får I aldrig den vækst, I så gerne vil have.

Et budskab der året efter blev sat tal på $\mathrm{i}$ et stort udredningsarbejde, the New Climate Economy anført af Mexicos tidligere præsident Calderon og med deltagelse af estimerede økonomer, nobelpristagere m.fl. Et af budskaberne var, at hvis bare vi begyndte med at investere de mange milliarder, der investeres hver eneste dag kloden over, 'rigtigt' og fremtidsrettet, ja så ville vi allerede nå et pænt stykke af vejen.

Verden er altså ved at vågne op: Politikerne, forvaltningerne, erhvervslivet, investorerne osv. 


\section{Gammelkendte stridspunkter}

Det betyder så desværre ikke, at Paris 'er hjemme. I de fire år, der nu er gået siden Durban vedtog, at alle lande skal bidrage til at løse problemet, er gammelkendte stridspunkter alligevel igen og igen dukket op i forhandlingerne: For det første CBDR. 'Common But Differentiated Responsibility', der betyder, at alle har et ansvar, men det er differentieret alt efter udviklingsniveau.

At en vis differentiering er nødvendig, bestrider de færreste. Problemet er, at CBDR ofte er blevet brugt til at legitimere, at der stadig skal være en opdeling i ilande, som skal være forpligtet til at gøre noget ved klimaet, og dem, som ikke skal, og som derfor heller ikke skal kunne kigges $i$ kortene.

Denne firewall har igen og igen forgiftet diskussionerne, ikke mindst set i lyset af, at verden ikke er statisk. Mange lande har haft en enorm udvikling siden inddelingen i de to grupper - Annex 1 og non-Annex 1 - blev lavet i 1990'erne. Hvis denne statiske inddeling endegyldigt kunne rives ned i Paris og som minimum erstattes af noget mere dynamisk, ville det være et stort skridt. Kender jeg forhandlingerne ret, bliver inddelingen ikke helt så skarp i det nye regime, men man skal næppe heller regne med at firewall'en helt forsvinder i et hug.

En anden principiel diskussion har været diskussionen om top/down eller bottom up: Altså skal man populært sagt forsøge at deles om opgaven og forpligte hinanden på det, som man forsøgte i bl.a. København og rigtig mange andre steder - top/down - eller skal man lade landene spille ind med, hvad de nu ønsker at gøre, og så er det det.

Det sidste har i mange år været USA's position, bl.a. fordi der ikke har været en situation i den amerikanske Kongres, hvor der har været udsigt til at få opbakning til en top/down aftale. Problemet med bottom/up tilgangen er, at den giver for få reduktioner - også i forhold til to graders-målet, der blev vedtaget i København. Så top/down giver for få, der vil være med, mens bottom/up giver for få reduktioner.

I de senere år har der derfor været arbejdet med en hybrid, hvor landene melder ind, hvad de mener, de kan gøre, og det skal så ses i relation til det fælles mål, og der skal være regler omkring implementering, der sikrer, at landene holdes fast på det, de har lovet at gøre. MRV hedder det i jargonen: Monitor, Report and Verify.

EU foreslog yderligere efter Durban en model, hvor man skulle kende landenes bidrag i god tid før Paris, for at der så kunne være tid til at se, om det samlet bragte verden langt nok, og hvis svaret var nej, ja så skulle man i gang med en ny runde. Mere end 150 lande har nu meldt ind til FN, hvad de agter at gøre. Derfor ved vi også, at det samlede bidrag ikke er nok til at holde temperaturen under de to graders stigning, som landene har forpligtet sig på. Derfor vil Paris skulle enes om en mekanisme for, hvordan man jævnligt - hver femte år bliver det formentlig - skal igennem øvelsen om, hvorvidt landene bl.a. qua ny teknologi etc. kan gøre yderligere.

\section{Behøver man en international proces?}

Men når nu landene selv har meldt ind, hvad de agter at gøre, behøver man så overhovedet den internationale proces? Efter min mening ja, for uden den ville for det første ikke nær så mange lande have meldt noget som helst ind. For det andet er meningen med en fælles over- 
ordnet ramme jo, at landene, der også i en global økonomi er hinandens konkurrenter, tør gøre mere, hvis de ved, at konkurrenterne også er forpligtet på at handle. Samtidig har man i årevis arbejdet hårdt for at sikre, at de forskellige bidrag er sammenlignelige: Hvilke gasser taler man om? Hvilke sektorer? Gælder målet dele af eller hele et lands økonomi? Er et lands bidrag rimeligt i forhold til landets velstandsog udviklingsniveau? Med andre ord er transparens også et centralt - og kontroversielt - emne.

Dertil kommer finansiering. Der er efterhånden bred - men ikke enstemmig accept af at klimabistand må gå til de fattigste og mest sårbare lande. Der er også større forståelse for, at klimaligningen ikke går op, med mindre de private investeringer tager fart. Omstillingen kan umuligt ske via offentlige midler alene. Med andre ord er den offentlige klimabistand fra de rige lande kun en del af det, der skal til. Ikke desto mindre er det naturligvis vigtigt, at ulandene kan se, at ilandene rent faktisk leverer på det, de lovede i København.

Meget er gjort, men dels mangler noget stadig at blive leveret, dels er ilandene normalt ikke ret dygtige til at vise, hvad de rent faktisk gør. Det kan blive fuldstændig afgørende for klimakonferencen i Paris og for det politisk-psykologiske klima omkring den, at ilandene kommer med et troværdigt narrativ omkring finansieringen.

Der er helt op til konferencens start stadig hjemmearbejde at gøre. Ikke mindst fordi mange af de fattigste lande allerede mærker klimaforandringer og derfor er mest optaget af at tilpasse sig dem, har de brug for, at der bliver leveret på klimabistanden, eftersom mange af tilpasningstiltagene vil have særdeles svært ved at tiltrække sig private investeringer.

\section{En global pris på $\mathrm{CO}_{2}$}

Der er mange andre elementer i spil i Paris - $\mathrm{fx}$ presser EU og andre på for at få fastsat et langsigtet globalt reduktionsmål - og så er der dem, man på forhånd har opgivet at blive enige om, herunder det redskab som de fleste vil være enig i er det mest virksomme værktøj, verden overhovedet har: En global pris på $\mathrm{CO}_{2}$. EU har i 10 år haft sit kvotesystem og mange andre er begyndt at følge efter. Senest Kina, som i september 2015 annoncerede, at de vil gå efter en landsdækkende prissætning af kulstof i den næste fem årsplan. Men så langt er man ikke i USA, og bl.a. derfor bliver det ikke en del af en Paris aftale.

Kan Paris så levere en aftale? Det burde Paris kunne. Den videnskabelige case er tilstrækkelig klar. Vi har tilstrækkelig viden om, hvad der kan gøres, der er masser af teknologier at gå i gang med, og oven i købet har vi brug for en mere bæredygtig udvikling også af mange andre grunde. Meget af det man skal gøre af hensyn til klimaet - renere energi, mere ressourceeffektivitet, bedre dyrkningspraksis, øget skovplantning og reduceret afskovning etc. etc. - ja, det har positive afledte effekter, som man bl.a. ser det i Kina, hvor mindre afbrænding af kul er tvingende nødvendig for at få styr på en luftforurening, der i mange af byerne har nået ekstreme og ekstremt skadelige niveauer.

En klimakonference reducerer ingen udledninger i sig selv. Og ingen forventer desværre et meget ambitiøst resultat $\mathrm{i}$ Paris. Men i en verden, hvor markedet er globalt, konkurrencen er global, investeringerne globaliseres, ja så er der behov for at sætte en fælles politisk ramme omkring indsatsen mod en af vor tids helt store globale udfordringer.

Selv om byer og business rykker, så 
sker det ikke 'automatisk' - det betyder noget, at der er en fælles ramme med alt hvad det indebærer. Derudover er forhåbningen, at en såkaldt 'Action Agenda' uden for de formelle Parisforhandlinger vil markere verdens vilje til at skifte kurs fx ved et forstærket klimafokus i byerne, hvor størstedelen af menneskeheden nu lever, ved at ændre investeringsstrømme og ved ikke bare i ord, men også i konkret handling at udfase subsidier til fossile brændstoffer, der den dag i dag støttes med fem dollar hver gang vedvarende energi støttes med én dollar. Ikke just logisk når alverdens regeringer erklærer sig enige $i$, at målet er at blive fri af fossile brændstoffer.

\section{Fransk diplomatis rygte på spil}

Da det for et par år siden var gået op for den franske udenrigsminister Laurent Fabius, hvad det indebar, at han skulle være formand for klimakonferencen i Paris, sagde han med glimt i øjet, at han havde forstået, at COP21 var en meget vigtig konference:

"Jeg har forstået, at det er hele klodens fremtid, der står på spil“, sagde han og tilføjede så "and even worse the reputation of French diplomacy."

Så... Der er ingen tvivl om, at franskmændene vil gøre sig maksimalt umage. Det er godt - men i FN-sammenhæng er det desværre ikke nok til at garantere et godt udfald. 195 regeringer vil komme til Paris med hver sin dagsorden; Claudia og alle de andre forhandlere har hver deres prioriteringer og hver deres bud på løsninger.

Men aldrig har det været mere presserende at de enes - og aldrig har mulighederne for en overordnet ramme for den globale klimaindsats været større. 